\section{BRS Tainá: new white seedless grape cultivar for the Brazilian semi-arid region}

\author{
Patrícia Coelho de Souza Leão ${ }^{1^{*}}$, Rita Mércia E. Borges ${ }^{1}$, Natoniel \\ Franklin de Melo ${ }^{1}$, Maria Angélica Guimarães Barbosa ${ }^{1}$ and \\ Maria Auxiliadora Coêlho de Lima ${ }^{1}$
}

\begin{abstract}
The new table grape cultivar BRS Tainá produces white firm seedless grapes, agreeable flavor, balanced sugar-acid ratio, good berry adherence to the pedicel and yield of 50 ton $\mathrm{ha}^{-1}$ year ${ }^{-1}$. It is recommended for the tropical conditions of the Submédio do Vale do São Francisco. Propagative material is acquired from nurseries licensed by Embrapa.
\end{abstract}

Keywords: Seedless grapes, tropical viticulture, plant breeding, Vitis sp.

\section{INTRODUCTION}

The Submédio do Vale São Francisco region is the main center of table grape production and export in Brazil, representing $36 \%$ of production and $14 \%$ of planted area in Brazil in 2019 (IBGE 2021). In 2020, this region, which includes the municipalities of Petrolina, PE, and Juazeiro, BA, produced 384 thousand metric tons of grapes (IBGE 2021), exporting 49.3 thousand tons, which represented an increase of $9 \%$ in volume and $13 \%$ in export value compared to 2019 (COMEXTAT 2021).

The social importance of this production chain is also noteworthy, as it generates at least four direct jobs per hectare and achieves high profitability in small areas, which allows grape growing to be an attractive and lucrative business in the Submédio do Vale São Francisco.

Each market is composed of particular preferences that define the buying decisions of its consumers. Recently published studies regarding the preferences of the table grape production sector in China indicated that important attributes for adoption of new table grape cultivars in that country include high yield, disease resistance, good post-harvest shelf-life, high sugar content, large ovalshaped berries of intense red and black color, as well as muscat flavor (Wang et al. 2017). Absence of seeds is also one of the main characteristics that attract fresh grape consumers, and most the table grape cultivars for exports in the world have this characteristic.

Over the past decade, big changes have taken place in the table grape production chain in the Submédio do Vale do São Francisco, and prominent among them are the diversification of cultivars and the increase in the supply of seedless grapes on the Brazilian domestic market. These changes have accompanied the growth trends in international public and private plant breeding programs for table grapes (Leão 2020).
Crop Breeding and Applied Biotechnology 21(3): e389321310, 2021 Brazilian Society of Plant Breeding. Printed in Brazil http://dx.doi.org/10.1590/1984$70332021 v 21 n 3 c 49$ 
In recent years, the demand for white seedless grape cultivars has increased as the traditional grapes 'Thompson Seedless' and 'Sugraone' have been eliminated, and even 'Italia' grape, the oldest and most traditional table grape cultivar of the Submédio do Vale São Francisco, has provided low economic return compared to the current seedless grape cultivars (Leão 2020). Considering the need for and importance of development of a new white seedless table grape cultivars for growing in the Submédio do Vale do São Francisco, the grape breeding program 'Uvas do Brasil' of Embrapa has developed the 'BRS Tainá' seedless grape. This is the first cultivar in which all steps of the breeding process, from crosses to validation, were performed in commercial areas under tropical semi-arid environmental conditions.

'BRS Tainá' has desirable characteristics for grapes for in natura consumption, such as firm berries and imperceptible traces of seeds. It has a pleasant neutral flavor, with a balanced sugar-acid ratio. In addition, the berries of this cultivar are moderately adherent to the pedicel.

\section{BREEDING METHODS}

'BRS Tainá' is the result of crossing between the seedless grapes 'Sugraone' (Vitis vinifera, 'Cardinal' $\times$ unknown) $\times$ 'Marroo Seedless' (interspecific hybrid, 'Carolina Blackrose' $\times$ 'Ruby Seedless') carried out in 2004. The parents were vines from the Active Germplasm Bank of Embrapa Semiárido in the Mandacaru Experimental Field (lat $9^{\circ} 24^{\prime}$ S, long $40^{\circ} 26^{\prime} \mathrm{W}$, alt $365.5 \mathrm{~m}$ asl), in Juazeiro, BA. The classic hybridization method was used, followed by selection of superior individuals in $\mathrm{F}_{1}$ progenies. The immature embryo rescue technique and growing in culture medium were used to recover plants, which is used when crosses are made between two seedless parents (Li et al. 2015).

A progeny with nine individuals was grafted on the rootstock IAC 572 Jales and planted in the field in 2006, performing agronomic evaluations in the period from 2008 to 2010, at which time four individuals of this progeny (CPATSA 15.03, CPATSA 15.04, CPATSA 15.05 and CPATSA 15.06) were selected and set up in an experimental design and evaluated over four production cycles during 2016 and 2017 in comparison with a commercial cultivar Sugraone, in two different locations, in the Experimental Mandacaru Field of Embrapa Semiárido in Juazeiro, BA and in a commercial vineyard in Petrolina, PE. Mean data for these four cycles were shown in Figure 1 and 2. In these experiments, cultural and phytosanitary management were carried out but gibberellic acid and other growth regulators were not applied for berry growth. In the period 2015 to 2019, the breeding selection CPATSA 15.06 was commercially validated, evaluating its production performance, physicochemical characteristics, quality, and post-harvest shelf-life, and its response to diseases. In 2019, the new seedless table grape 'BRS Tainá' was protected and registered in the Brazilian Ministry of Agriculture (Ministério da Agricultura, Pecuária e Abastecimento - MAPA).

\section{CULTIVAR CHARACTERISTICS}

\section{Ampelographic Characteristics}

The vines have shoots with a completely open tip, very low density of prostrate hairs, and absence of upright hairs at the shoot tip. The upper surface of the leaf blade in young leaves is green, whereas adult leaves have the following morphological characteristics: medium size, five lobes, orbicular shape, undulate transversal profile, absence of upright hairs over and between the main veins of the lower surface of the leaf blade, open upper lateral sinuses, convex base and slightly overlapping lobes, low anthocyanin pigmentation in the main veins of the upper surfaces of the leaf blade, and petiole shorter than the midrib. The branches have an upright growth habit; the dorsal side of the internode is red and the ventral side of the internode is green; they are absent of hairs and have medium to long tendrils. Flowers are perfect, with stamens and gynoecium completely developed. Bunches are of medium size, cone shaped, moderately compact, and with short peduncle. Berries are of medium size; have broad ellipsoid shape, yellowish-green color, moderate adherence to the pedicel, fine skin, firm pulp texture, and neutral flavor; and are seedless, with miniscule rudimentary seeds (Figure 3 ). The woody vine shoot has a yellowish-brown color.

\section{AGRONOMIC CHARACTERISTICS}

The 'BRS Tainá' seedless grape has a production cycle of around 110 days from pruning to harvest, with small variations throughout the year, as a result of climate conditions. The vines have high vigor, with intermediate bud 

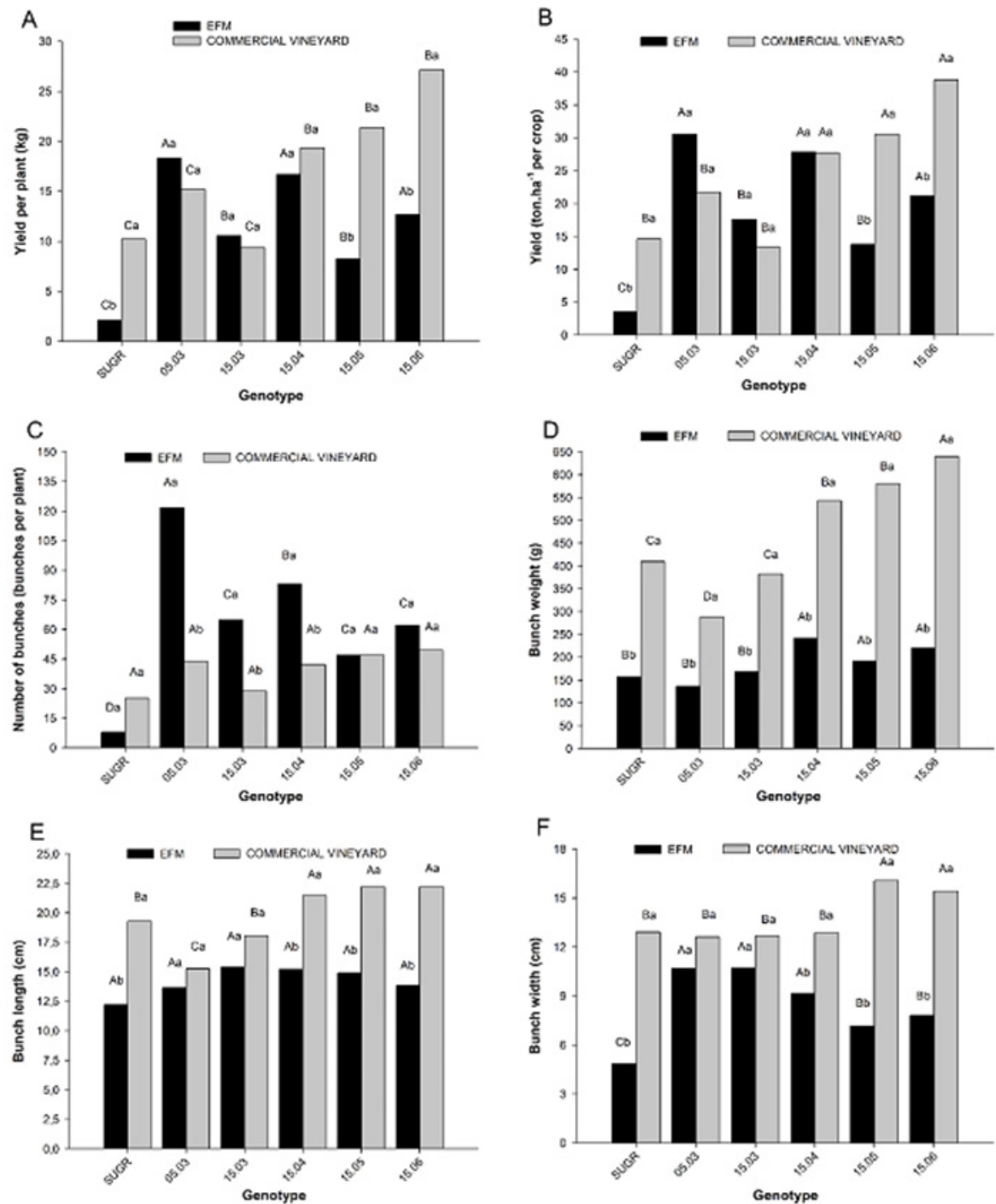

Figure 1. Genotype versus local interaction for yield per vine (kg per vine), yield (ton ha-1 per season), number of bunches, bunch weight $(\mathrm{g})$, bunch length $(\mathrm{cm})$ and bunch width $(\mathrm{cm})$ in two locations Experimental Field of Mandacaru (EFM), Juazeiro, BA and commercial vineyard, Petrolina, PE. Means followed by the same lowercase letter in the local and upper case for genotypes do not differ by Scott-Knott's test at the 5\% probability level. SUGR: 'Sugraone'

fertility between 0.6 and 0.7 bunches shoot ${ }^{-1}$ as of the third bud of the cane, which allows short pruning (four buds on the cane).

The mean number of bunches per plant under suitable management conditions was 55, which corresponded to a mean yield of $14.5 \mathrm{~kg}$ per vine, with small variations between the 'Paulsen 1103' and 'SO4' rootstocks. Mean estimated yield per cycle in the Submédio do Vale do São Francisco was 28 ton ha-1, with similar yield performance for the 'Paulsen 1103 ' and 'SO4' rootstocks. The grape bunches of 'BRS Tainá' were of medium size, with mean weight of $300 \mathrm{~g}$, measuring around $17 \mathrm{~cm}$ length and $11 \mathrm{~cm}$ width (Figure 4).

The berries had a mean natural size of $24.0 \times 19.0 \mathrm{~mm}$, increasing to $26.2 \times 20.9 \mathrm{~mm}$ when using $0.5 \mathrm{mg} \mathrm{L}^{-1}$ of gibberellic acid (17 days after pruning) and $30 \mathrm{mg} \mathrm{L}^{-1}$ over four applications $\left(5+5+10+10 \mathrm{mg} \mathrm{L}^{-1}\right)$, the first being applied when the berries were around $6 \mathrm{~mm}$ in diameter. Bunch management includes light berry thinning and growth regulators 

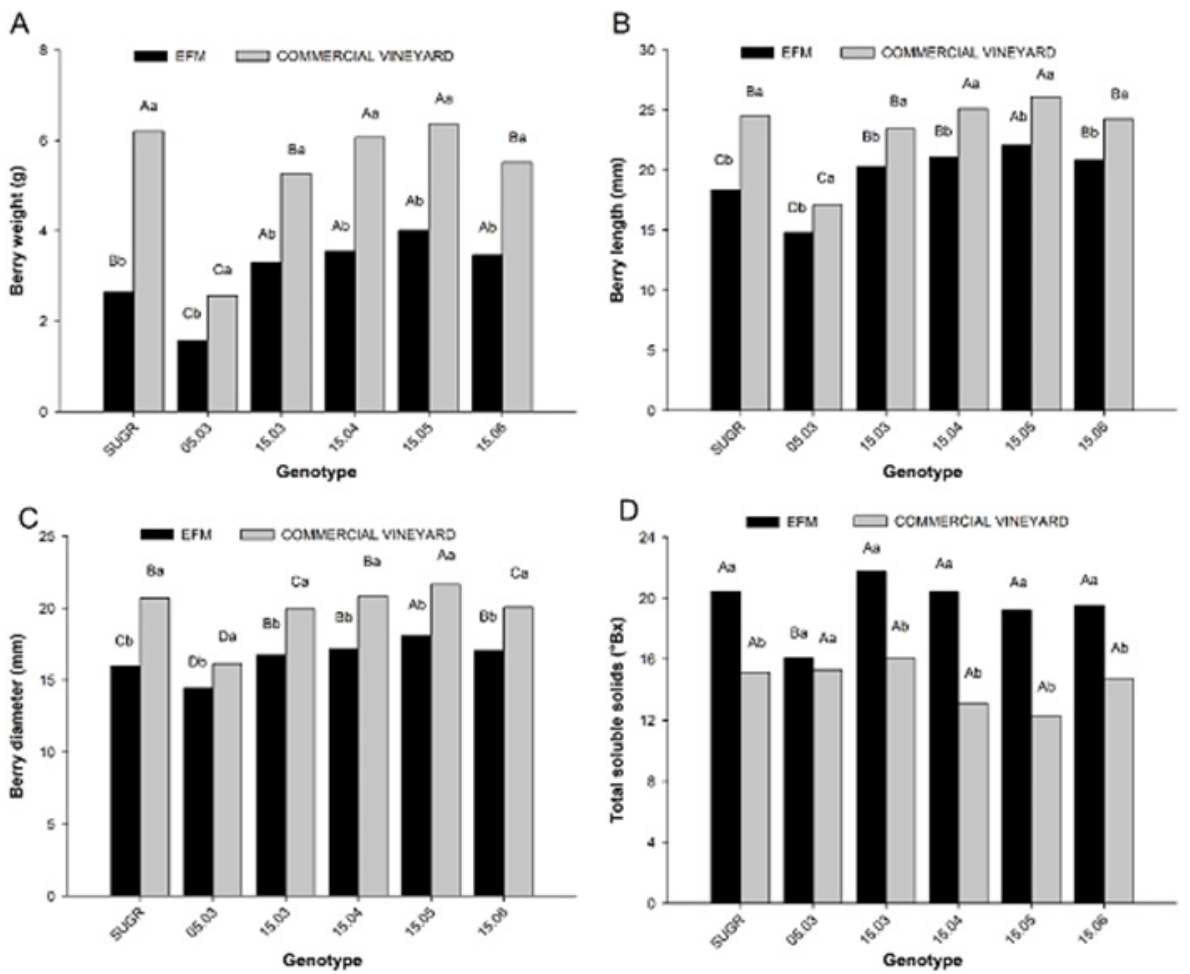

Figure 2. Genotype versus local interaction for berry weight $(\mathrm{g})$, berry length $(\mathrm{mm})$, berry diameter (mm) and total soluble solids ( ${ }^{\circ}$ Brix) in two locations Experimental Field of Mandacaru (EFM), Juazeiro, BA and commercial vineyard, Petrolina, PE. Averages followed by the same lowercase letter in the local and upper case letter to genotypes do not differ by Scott-Knott's test at the 5\% probability level. SUGR: 'Sugraone'

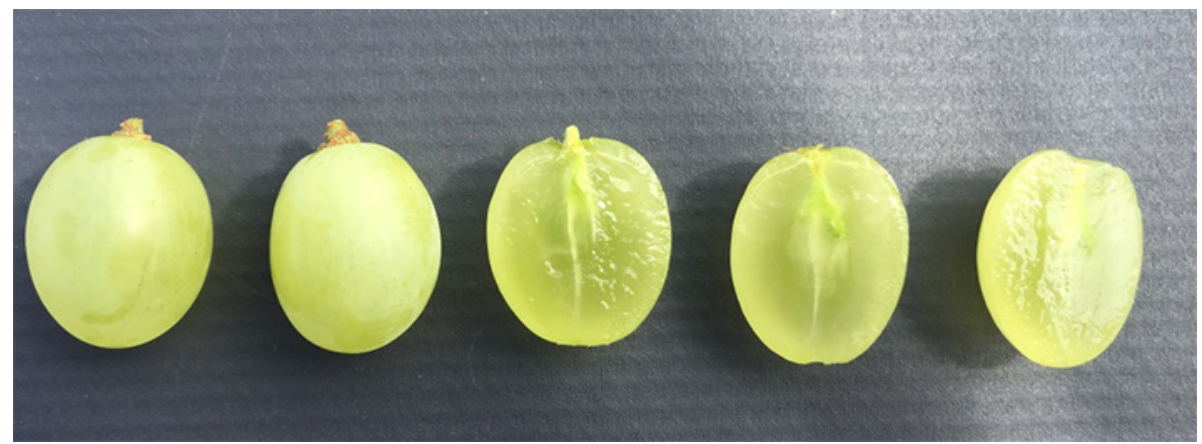

Figure 3. Berries cut lengthwise showing imperceptible traces of seeds.

combining gibberellins and cytokinins should be performed to promote berry growth and bunch development with standards acceptable for commercialization.

Ripe grapes of the cultivar BRS Tainá have the following characteristics: yellowish coloring of the skin (mean hue angle of 116.58-118.26), with medium lightness (values of 43.01-45.73), and low color purity (mean chroma value of 10.31-11.90), as a result of surface wax; considerable firmness (5.81-5.97 N) and berry resistance to compression (24.30$24.62 \mathrm{~N}$ ); and low titratable acidity (0.47-0.54\% tartaric acid), as shown in Table 1 . The soluble solids and polyphenol contents can reach around $19^{\circ} \mathrm{Brix}$ and $105 \mathrm{mg} 100 \mathrm{~g} \mathrm{~g}^{-1}$, respectively, under management conditions that prevent losses to synthesis or stimulus to degradation of these compounds that contribute to grape flavor. 
The cultivar BRS Tainá showed susceptibility to the main phytopathogenic agents of grapevine in the Submédio do Vale do São Francisco: bacterial canker of grapevines, caused by Xanthomonas citri pv. viticola (syn. $\times$ campestris pv. viticola), downy mildew (Plasmopora viticola), and powdery mildew (Erysiphe necator). During the period of validation tests, the incidence of rust (Phakopsora euvitis) was not present in the field. Studies to determine the degree of susceptibility to this pathogen are being conducted under field conditions.

\section{Harvest and post-harvest}

In spite of the differential of high berry firmness compared to most commercial cultivars, the skin of the 'BRS Tainá' grape shows damage from handling or damage caused by direct contact with hard surfaces. This damage causes light brown-colored blemishes, localized surface darkening. Care during harvest and placement of bunches in containers or even in packaging is fundamental to prevent this type of problem.

To preserve quality and for sale to more distant markets, the grapes should be stored under refrigeration at a temperature of $0 \stackrel{\circ}{ } \mathrm{C}$ and minimum relative humidity of $85 \%$, with recommendation of $90-95 \%$. Under these conditions, the grapes are to have been previously placed in cardboard boxes, surrounded internally by perforated plastic bags, while bunches are kept in plastic bags or in clamshell type polyethylene terephthalate (PET) packaging.

\section{Recommended growing area}

The new seedless grape cultivar BRS Tainá was validated in Petrolina, PE, Brazil, and is therefore recommended for growing in the Submédio do Vale do São Francisco.

\section{Propagative material}

The mother plants of the 'BRS Tainá' seedless grapes were tested in the biotechnology laboratory of Embrapa Semiárido using the ELISA method for detecting the presence of the main viruses that affect grapevines: GLRaV-1 (Grapevine
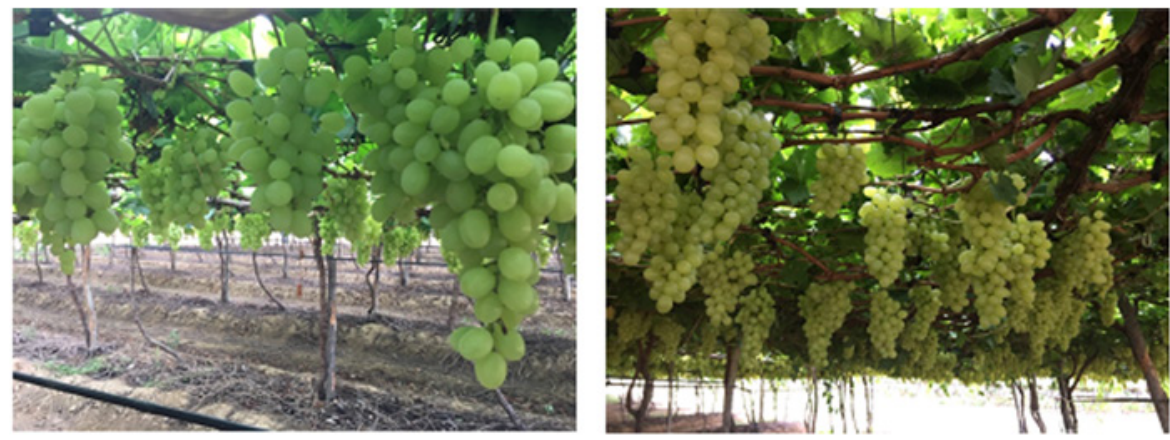

Figure 4. Grape bunches of the cultivar BRS Tainá, Petrolina, PE, Brazil, 2019.

Table 1. Quality characteristics of ripe grapes of the cultivar BRS Tainá: skin color, measured by lightness, chroma, and hue angle; firmness; resistance to compression; soluble solids content; titratable acidity; and polyphenol content

\begin{tabular}{lcc}
\hline \multirow{2}{*}{ Grape characteristic } & \multicolumn{2}{c}{ Harvest time } \\
\cline { 2 - 3 } Lightness & September 2018 & September 2019 \\
Chroma & $43.01 \pm 1.37$ & $45.73 \pm 1.48$ \\
Hue angle & $10.31 \pm 1.23$ & $11.90 \pm 0.90$ \\
Berry firmness (N) & $118.26 \pm 1.97$ & $116.58 \pm 2.34$ \\
Resistance to compression (N) & $5.81 \pm 0.43$ & $5.97 \pm 0.41$ \\
Soluble solids content ( ${ }^{\circ}$ Brix) & $24.30 \pm 3.04$ & $24.62 \pm 3.14$ \\
Titratable acidity (\% tartaric acid) & $14.0 \pm 1.5$ & $18.6 \pm 0.8$ \\
Polyphenol content (mg $\left.100 \mathrm{~g}^{-1}\right)$ & $0.54 \pm 0.09$ & $0.47 \pm 0.07$ \\
\hline
\end{tabular}


leafroll virus 1), GLRaV-2 (Grapevine leafroll virus 2), GLRaV-3 (Grapevine leafroll virus 3), GLRaV-7 (Grapevine leafroll virus 7), GVA (Grapevine virus A - Kober stem grooving), GVB (Grapevine virus B), GFLV (Grapevine fanleaf virus), GFkV (Grapevine fleck virus), ArMV (Arabis mosaic virus), and MLRsV (Myrobalan latent ringspot virus). Thus, only the vines with negative results for all the viruses were identified as healthy parent plants for obtaining propagative material and production of the basic plants for bud production for transfer to nurseries licensed by Embrapa. Propagative material of the new seedless grape 'BRS Tainá' can be obtained by ordering from nurseries licensed by Embrapa.

\section{REFERENCES}

COMEXSTAT - Sistema de Estatísticas do Comércio Exterior (2021) Exportação e importação geral. Available at <http://comexstat.mdic. gov.br/pt/geral>. Accessed on March 11, 2021.

IBGE - Instituto Brasileiro de Geografia e Estatística (2021) Pesquisa produção agrícola municipal. Available at <https://sidra.ibge.gov.br/ pesquisa/pam/tabelas>. Accessed on April 12, 2021.

cLeão PCS (2020) Produção de uvas sem sementes no Semiárido brasileiro.
In Aguila JS and Aguila LSH (Org) Vitivinicultura: função exata em cada processo. Atena, Ponta Grossa, p. 70-81.

Li Jun WX, Wang $X$ and Wang $Y$ (2015) Embryo rescue technique and its applications for seedless breeding in grape. Plant Cell and Tissue Organ Culture 120: 861-880.

Wang, Z, Zhou J, Xu X, Perl A, Chen S and Ma H (2017) Adoption of table grape cultivars: An attribute preference study on Chinese grape growers. Scientia Horticulturae 216: 66-75. 